\title{
THE OLD EAST SLAVIC TOPONYM KYJEVЪ IN THE ARAB-MUSLIM GEOGRAPHICAL LITERATURE
}

Keywords: the Arab-Muslim geographical literature, Kyjevo, the Caspian Codex, formative model, transcription

\begin{abstract}
The article deals with the transcriptions of the Old East Slavic toponym Kyjevz as found in the Arabic classical geographical literature. The author critically assesses the latest contributions to the study of this toponym and the respective readings offered by the orientalists since the times of Christian Martin Frähn. Based on the well-known readings and paleographic reconstructions, the author elaborates on several formative models (stemmata) of the Arabic transcriptions of the toponym Kyjevz which are all interrelated and chronologically attuned to the prehistorical change $k \bar{u}->k \bar{\imath}$ in Common Slavic.
\end{abstract}

\section{Introduction}

The name of the Ukrainian city Kyjiv has long been the focus of numerous studies concerned with the origin and attestations of this toponym in Slavic and non-Slavic languages. As a starting point for discussion, one always takes the Old East Slavic toponym Kyjevo as attested in the oldest extant East Slavic annalistic text, the Primary Chronicle, a compilation of two thematically distinct textual components brought together in the beginning of the $12^{\text {th }}$ century; the segment consisting of tales dealing with the introduction of Christianity in Rus' offers a typical legend of a medieval town's foundation. According to the 1377 Laurentian Redaction of the Primary Chronicle: 
dwelt upon the hill now named Ščekovica, while on the third resided Xorivo, after whom, this hill is named Xorevic. And they built a town and named it Kijevo [instead of Kyjevø] after their oldest brother (PC: 9; Laur. 1377: 54).

In the latest interlinear collation and paradosis of the Primary Chronicle, one finds the etymological spelling (with the back $y$ rendered by Cyrillic $b l$ ) of the form Kyi

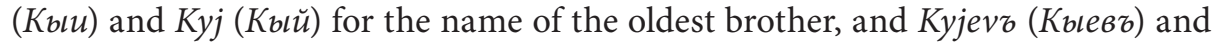
Kyjevb (Kolebs) for the name of the town (Ostrowski 2003 vol. 1: 44, 46). As Strumiński (1996: 121) pointed out, and rightly so, the Slavic form "town" should be better translated as 'a small fortified town'; in fact, some redactions of the Primary Chronicle have the diminutive forms gorodok $r$ and gradoks in place of Church Slavonic gradr in the aforementioned excerpt from the Laurentian codex (Ostrowski 2003 vol. 1: 45). What is important for our discussion is the fact that the name of Kyjb serves as the eponym of Kyjevz > Kyjiv because such is the logic of Slavic world formation (Strumiński 1996: 122; Trubačev 2003: 145).

In this paper, I review the aforementioned "logic" with the help of Arabic transcriptions of the Old East Slavic toponym Kyjevo which have been recently misconstrued by Nazarenko (2010) in his pursuit of refuting the traditional interpretation of the transcriptions found in the Arab-Muslim geographical output (see Ahmad 1995; Kračkovskij 2004). ${ }^{1}$ Accordingly, in Section 2, I provide a brief overview of Nazarenko's counterarguments followed, in Section 3 , by a reassessment of the transcriptions of the toponym Kyjivo in Arabic-Islamic records. It is my intention, based on the achievements made by the Polish oriental school, to make the respective transcriptions arranged in a more comprehensible way so that the Slavists, who are not familiar with the medieval Arabic-Islamic source material, can use them in further discussions on this subject.

\section{Issues of relative chronology}

Nazarenko (2010: 86) refuted the Arabic attestations as chronologically unreliable for positing the prehistorical change of the hypothetical ${ }^{*}$ Kujevo to the historically attested Kyjivz. At first blush, his major argument looks compelling. Nazarenko (2010: 86) claimed that all of the available Arabic transcriptions, in addition to the Latin form Cuiewa attested in the $11^{\text {th }}$-century Chronicon Thietmari, go to the mid-1 $10^{\text {th }}$ century and cannot reflect the earlier change $k \bar{u}->k \bar{\imath}$ in Common Slavic; in other words, Arabic Küyāba does not match chronologically "Old Russian" Kyjevó. Referring, in particular, to Zaxoder (1962: 49-51, 74-76, 1967: 101-102), Nazarenko (2010: 91) argued that the principle Arabic-Persian transcription Küyāba was incorporated by different Muslim geographers from a work authored in the early $10^{\text {th }}$ century

\footnotetext{
It should be borne in mind that the human geography of the Muslim world was intrinsically Arabic with two notable exception of two Persians, namely, the anonymous author of the Hudūd al-Ālam ('The Regions of the World', 982-983) (Minorsky1937) and Nāṣir-ī Khusraw (Miquel 1973: 2, fn. 2).
} 
by al-Balkhī. According to Nazarenko (2010: 91), a student deals in this case with one and the same attestation excerpted from al-Balkhïs account about three kinds of Rūs. This account was borrowed by al-Iștakhrī whose work was also prepared in Persian where Kyjiv is named Künaba which could be purportedly explained by a paleographic confusion of one and the same character in Arabic script (Nazarenko 2010: 91). ${ }^{2}$ Finally, to prove the chronological discrepancy between, on the one hand, the Arabic transcription Küyāba and its attested variants dating back to the $10^{\text {th }}$ century and, on the other hand, Old East Slavic Kyjevo alongside the Byzantine Greek forms like Kio $\beta \alpha$ and Kıo $\alpha \beta$ found in Constantine Porphirogenitus ( $10^{\text {th }}$ century), Nazarenko (2010: 93) surmised that all the aforementioned forms "testify unambiguously to the existence of Slavic Kyj- as early as the mid-10 $10^{\text {th }}$ century".

Taken at a closer inspection, Nazarenko's arguments look less persuasive. First, he erroneously provided the character $r \bar{a}$ ' in its isolated form $(\jmath)$ rather than its medial form as the paleographic reason behind the existence of different variants of the form Küyäba. Second, even if the respective passage goes back to the text authored by the Persian polymath al-Balkhī in the early $10^{\text {th }}$ century (Goeje 1871 ; Bejlis 1960: 81-86), one should bear in mind that al-Balkhī might have used different sources for his geographical treatise. ${ }^{3}$ These sources could retain the older form with the long $k \bar{u}$ - as attested in later compilations belonging to the early medieval "Central Asian-Khorasanian Codex" or, the "Caspian Codex" (Zaxoder 1962: 8, 26-33; Pritsak 1967: 3-4). In fact, the "Caspian Codex" could have appeared before the $10^{\text {th }}$ century, the date which is considered by Nazarenko as contradictory for the alleged change $k \bar{u}->k \bar{k}$. Ernst Eduard Kunik, a Russian historian of German stock, who, looking into al-Bakrīs Kitāb al-masālik wa-l-mamālik, brought attention to the secondary nature of the compilations made by Kardīzi ( $11^{\text {th }}$ century) and Ibn Rusteh (903-913); according to him, their accounts had been based on the primary text authored by a polymath living either at the very end of the $9^{\text {th }}$ century or in the very beginning of the $10^{\text {th }}$ century (Rozen, Kunik 1878: 65-67; Marquart 1903: xxxi). As early as 1928, based on Jaubert (1836-1840: xix), Reinaud (1848: 1xiii) and his other predecessors (see Smirnov 1928: 172; Bejlis 1960: 82; Kračkovskij 2004: 290) assumed that al-Balkhī might have used the geographical work of al-Jayhānī, who was active at the court of the Samanids in the $10^{\text {th }}$ century, as revised by Ibn al-Faqih in 903 (see Zimonyi 2016: 7-10, 13-15).

This said, there appear to be weak grounds for positing a chronological discrepancy between the Arabic transcriptions and the actual vowel sound observed in Old East Slavic Kyjevъ. Assuming that the weak grounding is correct, the fact that

2 Zaxoder (1967: 102) cited in fact Küyāna as found in the Persian-language version of al-Iștakhrî̀s $10^{\text {th }}$-century Kitāb al-masālik wa-l-mamālik (Liber viarum et regnorum) (see Seippel 18961928: 07) which is held at the depository of the Institute of Oriental Studies of the Russian Academy of Sciences. Zaxoder mentioned also the parallel passage with the form Küyāba in the Persian work Hudūd al-'̄lam 'Regionis mundi' (982-983) (see Minorsky 1937: 159)

3 Al-Balkhī wrote his geographical work in 920, or a little later in his old age (Barthold 1937: 15). The work was probably entitled Suwar al-Aqālìm ('Mappa orbium terrestrium'), although the correct title is yet to be established (Ahmad 1995: 76). 
Küyāba became widely accepted can be tentatively explained by parallel Byzantine Greek forms attested in Chapter 9 of the De Administrando Imperio by Constantine

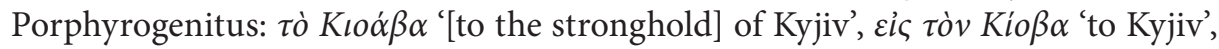

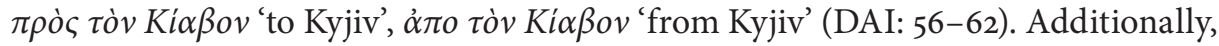
leaving aside the discussion of Arabic phonological constraints affecting transcription of Slavic words (Lewicki 1945: 100-101; Pauliny 1999: 11-15; Lewicka-Rajewska 2004: 15-19; Danylenko 2020: 16-19), I concur with Strumiński (1996: 125) that the Arabic transcriptions might be older than the Greek $10^{\text {th }}$-century names of Kyjevz. Indirectly this assumption is corroborated by the first attestation of the Old East Slavic name Kyjevs coming also from the $10^{\text {th }}$ century: 2 ' Pייוב in a letter by the Jewish community of Kyjevo from the first half of the $10^{\text {th }}$ century (Golb, Pritsak 1982: 12).

In the remainder I concentrate on the formative models of the well-known Arabic transcriptions of the toponym Kyjevz and the reconstruction of their stemmata as I did it for the name Rus' (Danylenko 2004, 2006: 3-30).

\section{Transcriptions of the toponym Kyjevъ}

Returning to the Caspian Codex, the accessible source material allows to posit two versions of al-Balkhīs account about three kinds of Rūs: the older, by al-Ișțakhri in his Kitāb al-masālik wa-l-mamālik ('Liber viarum et regnorum', first redaction 930-933; second redaction 950) (Kračkovskij 2004: 197), and the younger by Ibn Hawqal in his Șūrat al-ard ('Liber imagines terrae', first redaction 967; second redaction 977) (Kramers 1932: 16-17; Pritsak 1967: 3-4; Kračkovskij 2004: 199). Transferred into the later compilations, the underlying Arabic transcription of the name Kyjevo could have become misconstrued due to common copyist's errors (Lewicki 1956: 103-106; Pauliny 1999: 11-15).

In al-Iștakhrī's account about three kinds of $R \bar{u} s$, one comes across the transcription كويابه / كُويَّابَّ (Kūyāba / Kūyābah):

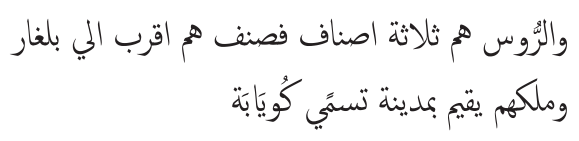

(al-Ișțakhrī, Yr Y-rYo)
And there are three kinds of Rūs, and one of them is close to the Bulghar, and their prince resides in the town called Kūyābah. ${ }^{4}$

The same transcription is repeated in Ibn Hawqal's Șūrat al-arḍ which was largely based on al-Ișțakhrî’s passage (see Reinaud 1848: lxxxiii-lxxxiv; Kramers 1938 1939: 397). The reading Küyāba is attested in some other sources influenced by the Caspian Codex, in particular in the Persian treatise Hudüd al-'Álam (982-983) which provides a description of Kyjiv and its inhabitants: "Küyāba is the town [land?] of the $R \bar{u} s$ lying nearest to the Islamic lands” (Minorsky 1937: 159).

\footnotetext{
4 The translation from the Arabic here and hereafter is mine.
} 
The reading Kūyāba was first proposed by Christian Martin Frähn, a Russian historian of German stock, who used the Leiden manuscript of Ibn Hawqal's work where the transcription of the toponym Kyjevz did not have consonant diacritics $K \bar{u} . \bar{a} . a$. Frähn (1823: 149, 257-259) offered the reading Küyāba, which became widely accepted, as well as Kūyāwa, although in total, one could come up with 24 different readings (see Frähn 1823: 149). ${ }^{5}$

Having taken into consideration the oldest Gotha Manuscript of al-Ișțakhrīs work dating back to 1173 and the latest publication of Ibn Hawqal by Kramers (1938-1939; see also Zimonyi 1990: 24-25), Pritsak (1967: 7) concluded that the transcription which unmistakably represented Kyjiv was transmitted in two otherwise identical variants; they were abstracted by the two geographers from the name of the third kind of $R \bar{u} s$ :

a) al-Iștakhrī has the name written with a tha', included in the geographical dictionary of Yāqūt who referred to the text of al-Ișțakhrī: كونابه (Kūthāba, see Frähn 1823: 147; Wüstenfeld 1869: 44, 318);

b) Ibn Hawqal spells it with a $y \bar{a}:$ كويابه (Küyāba).

To get a full picture of the various transcriptions of this name, one should resort to a transcription found in one of the later compilations in al-Idrīsīs Kitāb Rujār ('Liber Rogerii' 1138/1139-1153); thus, in Section 5 of Climate 6 in this work one finds an expression مدينة كadinah Kāw) (Opus, part 8: 912) 'town of Kāw', which was read by Jaubert (1836-1840, vol. 2: 398; Tuulio-Tallgren 1936: 136-138) as Kaw 'Kiew'. Al-Idrīsī in this case is, to be sure, less reliable as compared with Ibn Hawqal and even more so with al-Ișțakhrī (Novosel'cev 1965: 412; see Lewicki 1945: 35). At first sight, it is tempting to conclude that the transcription $K \bar{a} w$ may be a result of interference in oral communication or of a mere scribal mistake. In addition to the variant 6 with a sukūn above the $w \bar{a} w$, the extant eyewitnesses of the Kitāb Rujār have at their disposal three more graphic variants, to wit, كنار / كنار which all seem to testify to the inexact (corrupted) medial part of the transcription (see Konovalova 2006: 208).

In Section 6 of Climate 6 of the Kitāb Rujār the author offers, instead of the variant كؤيانة the spelling was read by Konovalova (2006: 232) as Kükiyāna. ${ }^{6}$ The Russian historian argued that this geographical name might have nothing to do with the name Küyāba, that is, Kyjiv as attested in earlier narratives about the three kinds of Rūs. According to Konovalova (2006: 232-233), the mention of Kükiyāna might have been added by al-Idrīsī in the description of Cuman towns; it is not therefore surprising that the town Kükiyāna was not indicated on the geographical map appended to al-Idrīsîss work.

\footnotetext{
To give an example of an alternative reading, one should mention the vocalization Küyāna in Tumanskij (1896-1897: 133; also Smirnov 1928: 194-195). In general, the multitude of different readings tend to make it difficult, according to Bejlis (1960: 85), to associate Küyāba with the name of the Old Ukrainian town.

6 In the edition of 1970-1983, among several variants one form is provided with a different final consonant and a different vowel diacritic above the second $k \bar{a} f$, that is, part 8: 917). This reading, however, does not affect a possible common denominator.
} 
If one agrees with the allegedly later insertion of this passage, then another assumption advanced by Novosel'cev may appear plausible. Without going into the phonological intricacies behind the respective transcriptions, Novosel'cev (1965: 416) asserted that the reading Küyāba is closer to the underlying East Slavic form, "and in some variants it is almost of the same type with that form". Novosel'cev's assertion is rather impressionistic from the linguistic point of view, although some sound correspondences were provided by Bejlis (1960: 85). In view of some modern dialectal forms like Ukrainian kujava 'a steep hill' or Polish kujawy 'sand hill' (Stryžak 1985: 79; see SJP, vol. 2: 621), Rospond's (1968: 106-110) hypothesis, although not fully corroborated in terms of relative chronology, seems to refute Novosel'cev's reasoning. Rospond argued, in particular, that the reading Kūyāva (also Kūyāba) changing into ${ }^{\star} K y j \bar{a} v a\left(\right.$ also $\left.{ }^{\star} K y j \bar{a} b a\right)$ is close to the Byzantine Greek attestations rather than to the actual name of the town, to wit, the patrial formation Kyjevo 'Kyjь's settlement'. This explanation still have some chronological counterarguments in regards to the change $k \bar{u}$ - > ki (cf. Nazarenko 2010: 86). ${ }^{7}$

In order to further expand the understanding of this transcription, Hrbek (1954: 170, 1955: 120) matched the reading Kaw 'Kiew' in Jaubert with the one recorded by Abū Hāmid al-Gharnāthī in his geographical work of 1162, bearing a religious and cosmographical stamp (see Lewicki 1951/1952; Hrbek 1955: 111-115); in section 24 of his work published by Dubler in 1953, one reads:

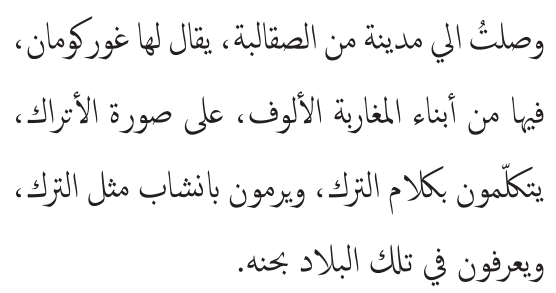

(Dubler 1953, Arabic text: 25)
And I arrived in a town of the Slavs called Ghürkūmān' where thousands of the descendents of the Maghribians live. They look like Turks, speak Turkish and shoot arrows like the Turks, and they are known in this land as H.n.h (cf. Dubler 1953, Spanish translation: 64; Hrbek 1955: 120).

Dubler (1953: 232) read the transcription غوركمان as Gür-Küman, where the first part could be connected to the concept of a fortified place, cf. $y v$ v $\alpha$ in Constantine Porphyrogenitus which is translated as 'rounds' (DAI: 62), and the second to the name of Cumans, a Turkic nomadic people; this reading, according to Dubler (1953: 233), would denote a Cuman stronghold: 'Fuerte Cumano'. Hrbek (1954: 170, 1955: 119) refuted the aforementioned reading since the respective place on the map reproduced by Dubler was to be found at the Prypjat' river draining into the Dnieper river, to wit, in the place of the modern Ukrainian city of Kyjiv. Hrbek (1955: 119) offered, instead, the following paleographic solution: غردوياو Ghurud Kīyāw as a construction of two Slavic words, Gorod(z) Kyjev(z) 'The town of Kyjiv'. Phonetically, this reconstruction looks plausible, at least in regards to the first component. First of all, in Slavic

For other hypotheses concerned with names of the Ukrainian toponym Kyjiv in Arabic-Islamic records, see Bejlis (1960: 86). 
transcriptions, the ghayn character $(\dot{\xi})$ stands for the Slavic velar stop [g] (Lewicki 1945: 116, 1956: xvi). Second, the presence of the $g$ sound in the form ${ }^{*} \operatorname{gorod}(\tilde{b})$ does not contradict the relative chronology of its spirantization which might have taken place in the late $12^{\text {th }}$ century (Shevelov 1979: 355 ).

Apart from Hrbek's reading, which looks paleographically, historically, and geographically feasible, one can posit the existence of two formative models (stemmata) of the transcriptions of the East Slavic toponym Kyjevz:

(1)

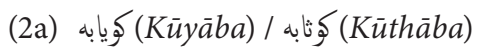

(2b) كويانه (Küyāna)

I argue that the formative model in stemma (1) is to be found outside the Caspian Codex. Stemma (2b), typical of the Caspian Codex, presents a transcription of an older East Slavic formative which looks ever more pronounced in stemma (2a). As in (2a), the reading Küyāna goes back to not earlier than the $6^{\text {th }}$ century since it still retains the back position of $k \bar{u}-(>k \bar{\imath})$ (Shevelov 1964: 267). The formative model as reconstructed for the transcription Küyāna may have derived from the name of the town of Kyjiv when it was still called Kyjb $\left(<{ }^{*} K \bar{u} j b\right)$ thus providing a logical base for the name of its inhabitants (Strumiński 1996: 125).

As Strumiński (1996: 126) argued, and rightly so, there is a formal sameness of $K y j b$, a name of the legendary founder of the town of Kyjiv, and Kyjb, a settlement name, from Late Common Slavic ${ }^{\star} K y j j b$ with the partial suffix $-j b$. The function of the latter suffix was the same as that of -evz/-ovz, although chronologically the patrial form ${ }^{\star} K y j j b$ antedated the appearance of the patrial formation Kyjevs 'Kyjb's settlement'. Phonetically, the patrial form ${ }^{\star} K y j j b$ was most difficult to be transcribed into Arabic which may explain the emergence of paleographically inexact $K \bar{a} w$ in stemma (1). There is, however, another possibility which was discussed by Lewicki (1938: 94-95). In a map attached to the manuscript of al-Idrīsī's Kitāb Rujār he proposed to reconstitute a $y \vec{a}$ ' after the $k \bar{a} f$; when reading this in the Maghrebic manner, one obtains $K(i) j \bar{e} w$ where the 'alif is replaced by an [ē] (Lewicki 1938: 95):

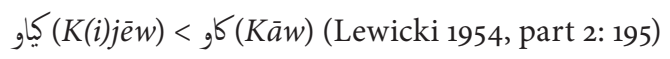

The proposed reading changes stemma (1) in that it represents a branching within the possessive (patrial) model based on the suffix -evo/-ovz:

(1a) كياو $(K(i) j e \bar{w} w)$

(1b),$\quad \zeta(K a \bar{w})$

One deals, therefore, with two major stemmata which all have paleographic variants. Stemma (1) and stemma (2) can be linked via model (1a) and model (2a). Within stemma 2, however, model (2b) Küyāna stands out. The latter may reflect the Early East Slavic ${ }^{\star} K \bar{u} j e ̌ n z ~(g a r d z)$ which could have been reflected in Old Scandinavian 
KonugardR (Trubačev 2003: 145); remarkably, the form Küjěnz (gardz) is still retained in folk oral tradition, cf. Kujanov gorod and the like (Schramm 2002: 197).

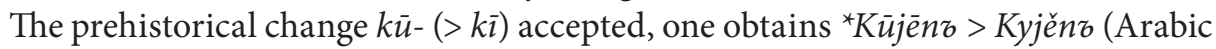
Küyāna) > Old East Slavic Kijane (988), Kyjaně (1024), Kyjany (1069), Kyjane (1093) 'Kyj's people/inhabitants' (Stryžak 1985: 78) where the patrial suffix -ěn- appears as - an-after a CS $+j$ sequence (see Andersen 2017: 8, 13). Old East Slavic Kievljane 'the inhabitants of Kyjiv' as reflected in the Primary Chronicle (Laur. 1377: 56, 67) is a result of a later contamination of model (1a) and model (2a) initially with a patrial meaning. This is why the new derivative with the semantics 'inhabitants of' is not attested in Early Medieval Arabic-Islamic geographical works.

\section{Conclusion}

As the foregoing survey shows (cf. Danylenko 2020: 27-33), there is no purported chronological discrepancy as postulated by Nazarenko (2010) between the $10^{\text {th }}$-century Arabic transcriptions of the type Küyāba of the toponym Kyjivo and the actual "Old Russian" (Old East Slavic or, Old Ukrainian) form Kyjevz. In fact, the stemmata of the formative models as reconstructed from the transcriptions found in the ArabMuslim geographical literature prove that the respective Arabic-Persian attestations go back, as was hypothesized as early as 1878 by Kunik, to the pre-Balkhi period, thereby retaining the back position of $k \bar{u}$ -

The variety of different transcriptions can be reduced to a few stemmata which belong to both the Caspian Codex and beyond it. Stemma (1) Kāw as found in alIdrīsīs Kitāb Rujār was first reconstructed by Lewicki and appears to represent a branching within the East Slavic possessive (patrial) model based on the suffix - evø/-ovr and can be therefore connected to stemma (2) via model (1a) K(i)jēw and model (2a) Kūyāba/Kūthāba. Stemma (2b) Kūyāna might reflect Old East Slavic $K \bar{u} j \bar{e} n \tau$ with the patrial suffix -ěn-; after the change $k \bar{u}$ - $>k \bar{\imath}$ had taken place, the East Slavic form transformed into Kijane/Kyjaně/Kyjany where the patrial suffix -ěn-appears as -an- after a $C S+j$ sequence.

In sum, the critique by Nazarenko is not incidental. The Slavists remain incognizant of the source material found in the Arab-Muslim geographical literature. The problem lies in how in the future one can bridge the gap between Arabic transcriptions and their interpretation by Slavists.

\section{References}

Ahmad S.M. 1995. A history of Arab-Islamic geography (9th-16th century A.D.). Amman. al-Iștakhrī = Goeje de M.J. (ed.). 1927. Bibliotheca Geographorum Arabicorum. Pars prima.

Viae Regnorum. Descriptio ditionis moslemicae autore Abu Ishák al-Fárisí al-Istakhrí. [2 $2^{\text {nd }}$ edition]. Leiden.

Andersen H. 2017. On Slověne and the history of Slavic patrials. - Scando-Slavica 63.1:3-42. 
Barthold V.V. 1937. Preface. - Minorsky V. (ed.). Hudūd al-'Alam 'The regions of the world'. A Persian geography 372 A.H.-982 A.D. [transl. from the Russian and expl. by V. Minorsky with the preface by V.V. Barthold ( $† 1930)]$. Oxford, London: 3-44.

Bejlis V.M. 1960. Pro nazvu Kyjeva v arabs'kyx heohrafiv X st. ta sproby jiji tlumačennja v istoryčnij literaturi. - Ukrajins'kyj istoryčnyj žurnal 1: 109-117.

DAI = Moravcsik Gy. (ed.). 2002. Constantine Porphyrogenitus. De administrando imperio. [= Dumbarton Oaks texts 1; new rev. ed.; Engl. transl. by R.J.H. Jenkins; vol. 1]. Washington (D.C.).

Danylenko A. 2004. The name Rus'. In search of a new dimension. - Jahrbücher für Geschichte Osteuropas 52.1: 1-32.

Danylenko A. 2006. Slavica et Islamica. Ukrainian in Context. Munich.

Danylenko A. 2020. What can the Arab geographers deliver on Slavic historical phonology? - Slavonic and East European Review 98.1: 1-34.

Dubler C.E. 1953. Abū Hāmid el Granadino y su relación de viaje por tierras eurasiáticas. Madrid.

Frähn C.M. 1823. Ibn-Foszlan's und anderer Araber Berichte über die Russen älterer Zeit. St. Petersburg.

Goeje de M.J. 1871. Die Istakhrī-Balkhī Frage. - Zeitschrift der Deutchen Morgenländischen Gesellschaft 25: 42-58.

Golb N., Pritsak O. (eds.). 1982. Khazarian Hebrew documents of the tenth century. Ithaca.

Hrbek I. 1954. Nový arabský pramen o východní a stř̌ední Evropě (Abū Ḥāmid al-Andalusī). - Československá ethnografie 2.2: 157-175.

Hrbek I. 1955. I. Abū Hāmid al-Andalusī und sein Werk "Mứrib". - Archiv Orientální 23: 109-135.

Jaubert A. (ed.). 1836-1840. Géographie d'Édrisi traduite de l'arabe en français d'après deux manuscripts de la Bibliothèque du Roi et accompagnée de notes par P. Amédée Jaubert. [2 vols]. Paris.

Konovalova I.G. 2006. Al-Idrisi o stranax i narodax Vostočnoj Evropy. Moskva.

Kračkovskij I.Ju. 2004. Arabskaja geografičeskaja literatura. [reprint of the 1957 edition]. Moskva.

Kramers J.H. 1932. La question Balhīiș̣tahrī-Ibn Hawḳal et l'Atlas de l'Islam. - Acta Orientalia 10: 9-30.

Kramers J.H. (ed.). 1938-1939. Opus geographicum auctore Inb Haukal. [= Bibliotheka geographorum arabicorum $2 ; 2^{\text {nd }}$ edition]. Leiden.

Laur. 1377 = Karskij E.F. (ed.). 1926. Lavrent'evskaja letopis'. [2 ${ }^{\text {nd }}$ edition]. Leningrad.

Lewicka-Rajewska U. 2004. Arabskie opisanie Słowian. Źródła do dziejów średniowiecznej kultury. Wrocław.

Lewicki T. 1938. La voie Kiev-Vladimir (Włodzimierz Wołyński), d’après le géographe arabe du XIIème siècle, al-Idrīsī. - Rocznik orjentalistyczny 13: 91-105.

Lewicki T. 1945. Polska i kraje sąsiednie w świetle "Księgi Rogera" geografa arabskiego z XII w. al-Idrīisiego. [part 1]. Kraków.

Lewicki T. 1951/1952. Ze studiów nad źródłami arabskimi. 1. Opis słowiańszczyzny w dziele podróżnika arabskiego Abū Hamida al-Andaluskiego. - Studia Antiqua 3: 136-154.

Lewicki T. 1954. Polska i kraje sąsiednie w świetle "Księgi Rogera" geografa arabskiego z XII w. al-Idrīsìego. [part 2]. Warszawa.

Lewicki T. 1956. Wstęp. - Lewicki T. (ed.). Źródła arabskie do dziejów słowiańszczyzny. [vol. 1]. Wrocław, Kraków: v-xvi.

Marquart J. 1903. Osteuropäische und ostasiatische Streifzüge. Leipzig. 
Minorsky V. (ed.). 1937. Hudūd al-Ālam 'The regions of the world'. A Persian geography 372 A.H. - 982 A.D. [transl. from the Russian and expl. by V. Minorsky with the preface by V.V. Barthold (†1930)]. Oxford, London.

Miquel A. 1973. La géographie humaine du monde musulman jusqu’au milieu du $11^{e}$ siècle. [2 $2^{\text {nd }}$ edition]. Paris.

Nazarenko A.V. 2010. K sporam o proisxoždenii nazvanija Kieva, ili o važnosti istočnikovedenija dlja ètimilogii. - Bertolisi S., Salvatore R. (eds.). Forma formans. Studi in onore di Boris Uspenskij. [vol. 2]. Napoli: 85-99.

Novosel'cev A.P. 1965. Vostočnye istočniki o vostočnyx slavjanax i Rusi VI-IX vv. Novosel'cev A.P. et al. Drevnee gosudarstvo i ego meždunarodnoe značenie. Moskva: 355-419.

Opus = Cerulli E. et al. (eds.). 1970-1984. Al-Idrīsī. Opus geographicum. [9 parts]. Naple, Rome.

Ostrowski D. (ed.). 2003. Pověst'vremennykh lět: An interlinear collation and paradosis. [3 vols]. Cambridge (MA).

Pauliny J. 1999. Arabské správy o Slovanoch (9.-12. storočie). Bratislava.

PC = Cross S.H., Sherbowitz-Wetzor O.P. (eds.). 1953. The Russian primary chronicle. Laurentian text. Cambridge (MA).

Pritsak O. 1967. The name of the third kind of Rus and of their city. - Journal of the Royal Asiatic Society 99.1: 2-9.

Reinaud M. 1848. Géographie d'Aboulféda traduite de l'arabe en français et accompagnée de notes et d'éclaircissements par M. Reinaud. [vol. 1]. Paris.

Rospond S. 1968. Značenie drevnerusskoj onomastiki dlja istorii: k ètimilogii toponima Kiev. - Voprosy jazykoznanija 1: 103-110.

Rozen V., Kunik A. 1878. Izvestija al-Bekri i drugix avtorov o Rusi i slavjanax. [part 1]. St. Petersburg.

Schramm G. 2002. Altrußlands Anfang: historische Schlüsse aus Namen, Wörtern und Texten zum 9. und 10. Jahrhundert. Freiburg im Bresgau.

Seippel A. 1896-1928. Rerum Normannicarum Fontes Arabici e Libris quum Typis Expressis tum Manu Scriptis Collegit et Sumptibus Universitatis Osloensis Edidit Alexander Seippel. Oslo.

SJP = Karłowicz J., Kryński A., Niedźwiedzki W. 1902. Słownik języka polskiego. [vol. 2]. Warszawa.

Shevelov G.Y. 1964. A prehistory of Slavic. Heidelberg.

Shevelov G.Y. 1979. A historical phonology of the Ukrainian language. Heidelberg.

Smirnov P. 1928. Volz'kyj šljax i starodavni rusy. [= Zbirnyk istoryčno-filolohičnoho viddilu 75]. Kyjiv.

Strumiński B. 1996. Linguistic interrelations in Early Rus'. Northmen, Finns, and East Slavs (ninth to eleventh centuries). Edmonton, Toronto.

Stryžak O.S. (ed.). 1985. Etymolohičnyj slovnyk litopysnyx heohrafičnyx nazv Pivdennoji Rusi. Kyjiv.

Trubačev O.N. 2003. Etnogenez i kul'tura drevnejšix slavjan. Lingvističeskie issledovanija. Moskva.

Tuulio-Tallgren O.J. 1936. Du nouveau sur Idrīsī. Édition critique, traduction, études. Helsinki.

Tumanskij A.G. 1896-1897. Novootkrytyj persidskij geograf X stoletija i izvestija ego o slavjanax i russax. - Zapiski Vostočnogo otdelenija Imperatorskogo russkogo arxeologičeskogo obščestva 10: 121-137.

Wüstenfeld F. (ed.). 1869. Jacut's geographisches Wörterbuch aus den Handschriften zu Berlin, St. Petersburg, Paris, London und Oxford (...). [vol. 4]. Leipzig. 
Zaxoder B.N. 1962. Kaspijskij svod svedenij o Vostočnoj Evrope. [vol. 1: Gorgan i Povolže]. Moskva.

Zaxoder B.N. 1967. Kaspijskij svod svedenij o Vostočnoj Evrope. [vol. 2: Bulgary, mad'jary, narody Severa, pečenegi, rusy, slavjane]. Moskva.

Zimonyi I. 1990. The origins of the Volga Bulghars. [= Studia uralo-altaice 32]. Szeged.

Zimonyi I. 2016. Muslim sources on the Magyars in the second half of the 9th century. The Magyar chapter of the Jayhāni tradition. Leiden. 
